\title{
A Comparative Study on the Allometric Relationship of Black Clam (VILLORITA CYPRINOIDES) in Cochin Estuary with a Special Emphasis on the Impact of Thanneermukkom Bund
}

\author{
A. U. Arun \\ Department of Zoology, St.Peter's College Kolenclhery, Kolenchery- 682311
}

\begin{abstract}
Regular tidal flow, estuarine circulation and other allied hydrographic parameters in the Cochin Estuary has changed due to regular closure and opening of bund. Among different hydrographic parameters temperature, salinity and bottom sediment texture are the important factors found to be significant for the growth and survival of bivalves. The environmental condition on either side of the bund; Zone A on south of bund and Zone $B$ on north of bund showed a clear and distinct variation in all the hydrographical parameters due to the existence of Thanneermukkom bund in between them. At Zone A the frequency of temperature fluctuation was high and the dominant environment was freshwater when compared with Zone B. Sediment texture at Zone $A$ was sandy silt and at Zone B was silty sand. The fitted regression was highly significant $(P<0.001)$ and explained a significant part of the variability in the data in all the cases. Allometric relationship existed between the factors taken for the study. Higher ' $r$ ' values especially in $L$ vs $B, L$ vs $D, L$ vsT.Wt, $L$ vs T.Vol, $L$ vs T.D.S.Wt and $L$ vs T.D.S. Vol at Zone $A$ and $L$ Vs $B, L$ vs T.Wt and $L$ vs T.Vol at Zone B were noticed in this study. Variation in allometric relationship was observed between organisms present at Zone $A$ and Zone $B$.
\end{abstract}

Keywords: bivalves, Thanneermukkom bund, Allometric relationships

\section{Introduction}

In bivalves, as in other animals, the growth rate of the various parts of the body may not be uniform with the result that the relative proportions of the body parts change with increase in size. A variety of environmental factors such as seasons, regions, salinity, temperature etc. influence the growth in molluscs. So an analysis of the growth of an organism as a whole and different parts with respect to its environment is important not only for interpreting its adaptation to environmental changes but also to understand the exact impact of rapidly changing environment on the species. In an environment the response of an aquatic organism varies with the 'physiological state' of the organism. Alterations in the growth pattern of different parts of the organism occur during definite stages of growth and different seasons, because increasing proportion of energy consumed by the organism is utilized for different purposes, hence a thorough knowledge on the growth of a bivalve mollusc as a whole and different parts of the body along with its different life stages and seasons is very imperative especially for the successful exploitation of its fishery potential. Due to the paucity of this information in molluscs in general, and in Villorita cyprinoides (Plate 2) in particular, an investigation on this aspect has been taken up to fill up the vacuum.

Age and growth studies provide an insight in to age class structure of the stock, changes in abundance and their relation to fishing. Shell dimensions of clams give an idea about the optimum marketable size of clams. Though many species of commercially important bivalves occur along the Indian coast, little attention was paid by past workers on various aspects of growth and allometric relationships despite the fact that this field offers a large number of unanswered questions.

Thanneermukkam bund was constructed (1974) to prevent salt-water incursion and to promote two crops of paddy in about 50,000 ha. of low lying fields in the Kuttanadu area. The bund has been functional since 1976 and remains closed from January to May every year. This has resulted in drastic ecological changes in the lake, particularly south of the bund, affecting the distribution, survival and abundance of the living resources in the estuary, and causing depletion of the black clam in several localities, besides this dredging conducted in several parts of the estuary has aggravated this problem.

\section{Materials and Methods}

\section{Study area}

Two sampling sites in Cochin estuary were selected for the estimation of allometric studies of Villorita cyprinoides. One site was selected south of Thanneermukkom bund (Zone A)(Plate 1) and another on the north of bund (Zone B). Regular fortnight sampling for hydrographic parameters was carried out from Zone A and Zone B for a period of two and half years (November 2013 to April 2016) and monthly hydrographic data was collected from Zone A and Zone B for two and half years (November 2013 to April 2016). Observation on Temperature, salinity and sediment texture have been given more importance because these factors were found to be more significant. Sampling for allometric studies was carried out for two and half years.

\section{Hydrographic parameters}

Among different parameters temperature was measured by ordinary thermometer, salinity by Mohr's titration method 


\section{International Journal of Science and Research (IJSR) \\ ISSN (Online): 2319-7064}

Index Copernicus Value (2016): 79.57 | Impact Factor (2015): 6.391

(Strickland and Parsons, 1968) and sediment texture by the method proposed by Carver (1971).

\section{Allometry and growth}

In the present study, the methods adopted were the lengthfrequencuy analysis, here allometric relationship between different dimensions. Study on the allometric relationship of Villorita cyprinoides was based on random samples collected fortnightly from two Zones (Zone A and Zone B) in Cochin estuary during the period between November 2013 and April 2016. Clams were collected using Van Veen Grab of $0.05 \mathrm{~m}^{2}$ capacity. Clams along with sediment were collected using the grab, and the sediment was sieved with $5 \mathrm{~mm}$ sieve so as to allow the sand to pass through the meshes leaving the clams in the sieve. Clams were then kept it in water of habitat nature. Length, breadth and depth of each clam were measured with vernier calipers correct to one-tenth of millimetre. The greatest anterior-posterior measurement was taken as length, the maximum distance between the hinge and ventral (free) margin of the valves as breadth, and the greatest distance between the outer surfaces of the two valves measured in a direction perpendicular to the anterior-posterior axis as depth. In order to determine the total weight, flesh meat weight, dry meat weight, and shell weight, the clams were kept in aerated water for 48 hours to defecate and weights were determined to the nearest $0.1 \mathrm{mg}$ in an electronic balance. Total weight and total wet meat weight were measured directly. For dry tissue weight the clam meat was kept in hot air oven at $60{ }^{\circ} \mathrm{C}$ overnight and weighed. Shell weight was determined by weighing the free shell (after removing the meat). Volume of whole organism and shells were determined by displacement method using measuring cylinders.

The relation of different morphometric parameters were studied by fitting the regression equation of the type,

$\mathrm{Y}=\mathrm{a}+\mathrm{b} \mathrm{X}$

When required, logarithmic transformation was applied by taking ' $\mathrm{Y}$ ' as the dependent variable, ' $\mathrm{X}$ ' as the independent variable, $\mathbf{a}$ and $\mathbf{b}$ (coefficients of allometry) the constants which are estimated by the least square method. Length was used as independent variable in all the studies. The allometric relationship between length (L) and other morphological parameters such as breadth (B), depth (D), total weight (T.Wt), total volume (T.Vol), total wet meat weight (T.W.M.Wt), total dry meat weight (T.D.M.Wt), total shell weight (T.S.Wt) and total shell volume (T.S.Vol), (L vs B, Lvs D, L vs T.Wt, L vs T.Vol, L vs T.W.M.Wt, L vs. T.D.M.Wt, L vs T.S.Wt and L vs T.S.Vol.) were worked out. The coefficient of correlation between different morphological parameters were calculated using Pearson's formula.

\section{Results}

\section{Temperature}

Significant variation in temperature at different stations during different seasons was observed in this study. Being a tropical estuarine environment the variation in bottom temperature was in similar trend to that of other tropical estuaries. While comparing stations on either side of bund, stations situated south of bund (Zone A) showed frequent fluctuation in temperature. At Zone A temperature varied from $33.8^{\circ} \mathrm{C}$ to $27.1^{\circ} \mathrm{C}$ and at Zone B it was between $33.5^{\circ}$ $\mathrm{C}$ and $27^{\circ} \mathrm{C}$ (Graph.1).

\section{Salinity}

The two stations (Zone A and Zone B) had a freshwater dominated environment with measurable salinity occurring only during pre - monsoon. (Graph. 2).

\section{Sediment Texture}

The substratum acts as an important abiotic factor in the benthic environment, by its mere physical condition. At Zone A the substratum was always silty sand except in March, April and May. During March it was sandy silt but in April and May it was clayey silt (Graph.3,4 and 5). At Zone $\mathrm{B}$ the dominant sediment texture was sand except during June. (Plate.3)

\section{Allometric relationships}

A well defined allometic relationship was noted in the present study at Zone A and Zone B (Graph.6 and 7). The fitted regression is highly significant $(\mathrm{P}<0.001)$ and explains a significant part of the variability in the data in all the cases. Higher ' $r$ ' values, especially in L vs B, L vs D, L vsT.Wt, L vs T.Vol, L vs T.D.S.Wt and L vs T.D.S.Vol at Zone A and $\mathrm{L}$ Vs B, L vs T.Wt and L vs T.Vol at Zone B were noticed in this study. Comparing Zone A and Zone B , it was noticed that better allometric relationship between different morphometric parameters were observed in Zone A. Considering ' $\mathbf{b}$ ' value and '- $\log \mathbf{a}$ ' value it was observed that except in L vs B relationship, Zone A showed a higher values than Zone B (Table $1 \& 2$ ). At Zone A, L vsT.W, L vs T.Vol, L vs T.W.M.Wt, L vs T.D.M.Wt, L vs T.D.S.Wt and L vs T.D.S.Vol showed ' $b$ ' values higher than 3, whereas at Zone B L vs T.Wt, L vs T.D.S.Wt and L vs T.D.S.Vol showed ' $b$ ' values higher than 3 and L vs T.Vol, $\mathrm{L}$ vs T.W.M.Wt and $\mathrm{L}$ vs T. D.M.Wt showed ' $b$ ' values higher than 2. Logarithmic relationships between different morphometric parameters at Zone A (Graph.6) and Zone B (Graph.7) showed a linear relationship (straight line).

Analysis of Co-Variance (ANACOVA) showed that there was a significant difference between stations in allometirc relationships, namely L.vs T.Wt, L vs T.Vol, $\mathrm{L}$ vs T.W.M.Wt, L vs T.D.M.Wt, L vs T.S.Wt and L vs T.S.Vol at $25 \%$ level (Table.1 and 2 ). Regarding L Vs B and L Vs $\mathrm{D}$ there was no much significant difference between stations.

\section{Discussions}

It was observed that relationship between different morphometric parameters were linear. Similar observation was made by Mane (1974) in Katelysia opima; Talikhedkar et.al, (1976) in Donax cuneatus, Nair et al., (1978) in Donax incarnates, Dang et al.(2008), Watanabe and Katayama. (2010), Katsanevakis,et.al (2007) and Fan et.al (2007) in Ruditapes philippinarum and Spillman et.al (2009) in Tapes philippinarum,. Comparing Zone A and Zone B it was seen that there are some sort of difference between the allometric relationship between stations, The reason for this may be attributed to the variation of environmental parameters in that location ie., the predominant nature of substratum at Zone A was sandy silt and the medium was

\section{Volume 6 Issue 12, December 2017}




\section{International Journal of Science and Research (IJSR) \\ ISSN (Online): 2319-7064}

Index Copernicus Value (2016): 79.57 | Impact Factor (2015): 6.391

freshwater, whereas at Zone B it was silty sand and the ambient medium was saline. Belding $(1916,1930)$ found that the dimensions of Mya arenaria shells varied among sediment types; clams collected from mud were both 'wider" and "thicker" than clams from sand. According to Wilbur and Owen (1964); Kim et al.(2006), Gaspar et.al (2002 and 2004) and Costa (2008) a variety of environmental factors are known to influence shell form in bivalves. Shell length to shell breadth, and shell length-depth relationships showed a linear growth pattern and the calculated ' $b$ ' values were 0.88 and 1.12 at Zone $A$ and 0.883 and 1.05 at Zone respectively in the present investigation. A positive linear relationship has observed between shell length and other morphometric parameters as reported by Chatterjii et.al., (1984) in Villorita cyprinoides from Colvale river Goa.

Hence, it can be concluded that existence and periodical opening and closure of Thanneermukkom bund has been destroying the ecology of clam beds and threatening the very existence of clams in the estuary. So proper management measures should be taken to maintain the ecology of clam beds and clam fishery of this estuary.

\section{Acknowledgement}

The author thanks the Principal St.Peter's College, Kolenchery and Head, Dept of Marine Biology, Microbiology and Biochemistry, School of Marine Sciences, Cochin University of Science and Technology for the permission and help rendered during the study. I also thank those persons who helped me in bottom sampling and analysis.

\section{References}

[1] BELDING, D.L., 1916. A report upon the clam fishery. 50 ${ }^{\text {th }}$ Ann. Rep., Mass. Comm. Fish and Game (1915) Public Document, 25 : 93 - 234.

[2] BELDING, D.L., 1930. The soft - shelled clam fishery of Massachusetts. Commonwealth of Massachusetts. Mar. Fish. Ser., 1 : 65.

[3] CARVER, R.E., 1971. Procedure in Sedimentary petrology. Willey, New York, 653 .

[4] CHATTERJI, A., Z.A ANSARI \& A.H. PARULEKAR., 1984. Growth of the Black Clam, Villorita cyprinoides (Gray) from Colvale River (Goa). Indian Journal of Marine Sciences., .13: 119 - 120.

[5] COSTA,C, AGUZZI,P MENESATTI,J ANTONUCCI,F RIMATORI V, \& MATTOCCIA, M 2008 Shape analysis of different populations of clams in relation to their geographical structure, Journal of Zoology, 276(1); 71-80,.

[6] DANG,D, De MONTAUDOUIN,X, GONZALEZ ,P,MESMER-DUDONS N, and CAILL-MILLY N, 2008.Brown muscle disease (BMD), an emergent pathology affecting Manila clam Ruditapes philippinarum in Arcachon Bay (SW France), Diseases of Aquatic Organisms, 80(3), 219-228,

[7] FAN, C, ZHANG.A, YANG.Y, \& SUN ,X. 2007. "Observations on shell growth and morphology of the bivalve Ruditapes philippinarum," Chinese Journal of Oceanology and Limnology, 25(3), 322-329,

[8] GASPAR, B. MIGUEL N. MIGUEL SANTOS, PAULO VASCONCELOS and CARLOS MONTEIRO.C 2002. Shell morphometric relationship of the most common bivalve species (Mollusca: Bivalvia) of the Algarve coast (southern Portugal). Hydrobiologia, (477): 73-80.

[9] GASPAR, M.B., M.N. SANTOS and P. VASCPMCELOS 2001. Weight- length relationship of 25 bivalve species (Mollusca: Bivalvia) from the Algarve coast (southern Portugal). J. Mar. Biol. Ass. U.K., 81: 805-807.

[10] KATSANEVAKIS， S，THESSALOU-LEGAKI,M, KARLOU-RIGA， C， LEFKADITOU, E, DIMITRIOU,E, and VERRIOPOULOS,G, 2007.Information-theory approach to allometric growth of marine organisms, Marine Biology, 151(3), 949959.

[11] KIM, Y. H., RYU, D. K., LEE, D. W., CHANG, D. S., JONG, B. K., KIM, S. T., and KWON, D. H., 2006. Morphological analysis among populations of purpulish Washington clam, Saxidomus purpuratus on the Korean waters. The Korean Journal of Malacology, 22(1): 23-26.

[12] MANE, U. H., 1974. Growth and breeding habits of the clam Katelysia opima in the Kalbadevi estuary at Ratnagiri. Indian Journal of Fisheries., 21 : 386 - 398.

[13] NAIR, A., DALAL, S.G \& ANSARI, Z.A., 1978. Growth of the bean clam, Donax incarnates (Gmelin) from a sandy beach at Benculin, Goa. Indian J. Mar. Sci., 7 : 197 - 199.

[14] SPILLMAN.C.M, HAMILTON,D.P, and IMERGER, J,.2009 Management strategies to optimise sustainable clam (Tapes philippinarum) harvests in Barbamarco Lagoon, Italy,Estuarine, Coastal and Shelf Science, 81(2): 267-278.

[15] STRICKLAND, J.D.H \& PARSONS, T.R., 1968. A manual of seawater analysis. Bull No.167 ( Fishery Research Board Canada).

[16] THALIKEDKAR, P.M., MANE, U.H \& NAGABHUSHANAM, R., 1976. Growth rate of the wedge clam, Donax cuneatus, at Mirgabay, Ratnagiri. Indian Journal of Fisheries. 23(1-2) :183-193.

[17] WATANAE,S \& KATAYAMA.S.2010. Relationships among shell shape, shell growth rate, and nutritional condition in the manila clam (Ruditapes philippinarum) in Japan, Journal of Shellfish Research, 29(2): 353-359.

[18] WILBER, K.M. and G. OWEN., 1964. Growth. In K.M. Wilber and .M. Younge (editors), Physiology of molluscs, Vol.1, 211-242. Academic Press. N.Y. wild life service, 51: 59-186. 
International Journal of Science and Research (IJSR)

ISSN (Online): 2319-7064

Index Copernicus Value (2016): 79.57 | Impact Factor (2015): 6.391
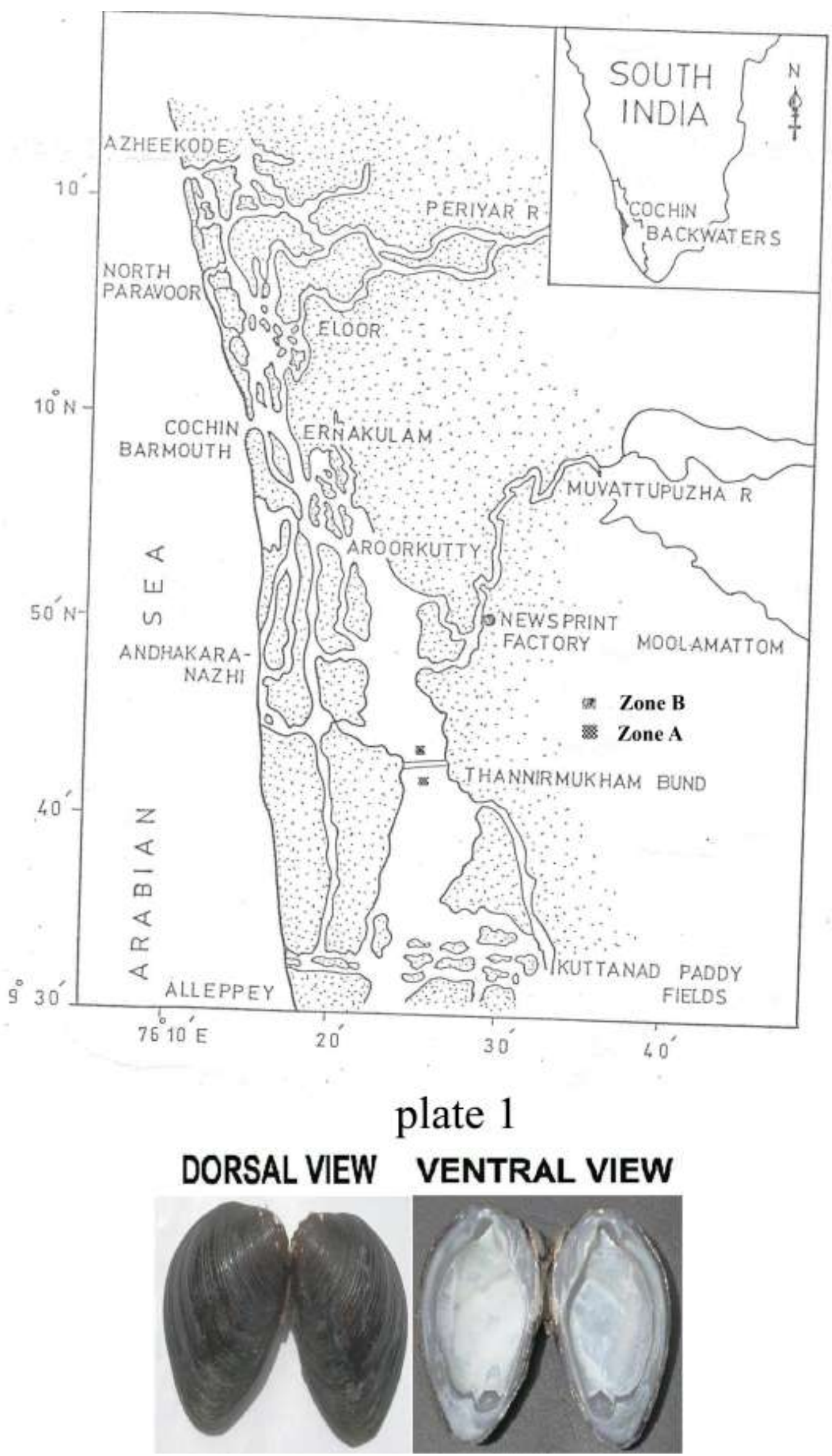

Volume 6 Issue 12, December 2017

www.ijsr.net

Licensed Under Creative Commons Attribution CC BY 


\section{Villorita cyprinoides}
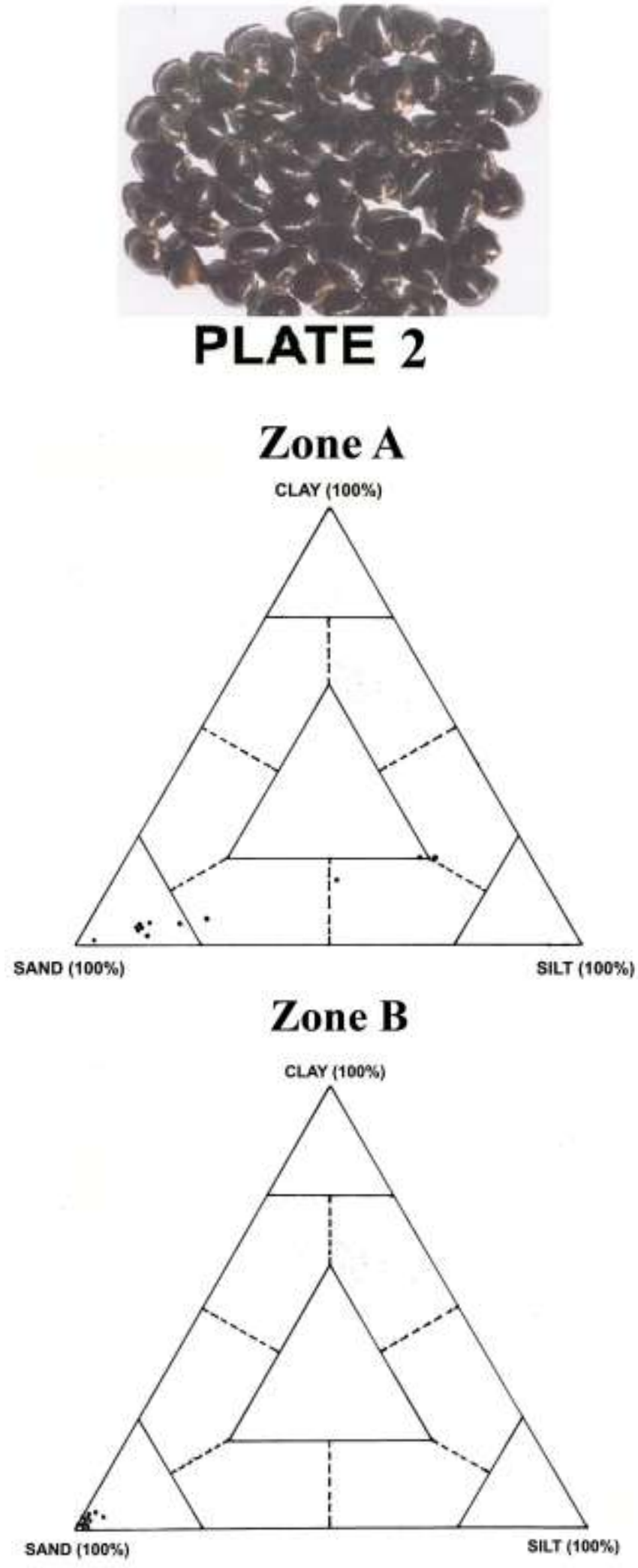

\section{PLATE 3}

Graph 1: Monthly variation in temperature

Volume 6 Issue 12, December 2017

www.ijsr.net

Licensed Under Creative Commons Attribution CC BY 
$-\bullet-$ Zone A

$-\square$-Zone $B$

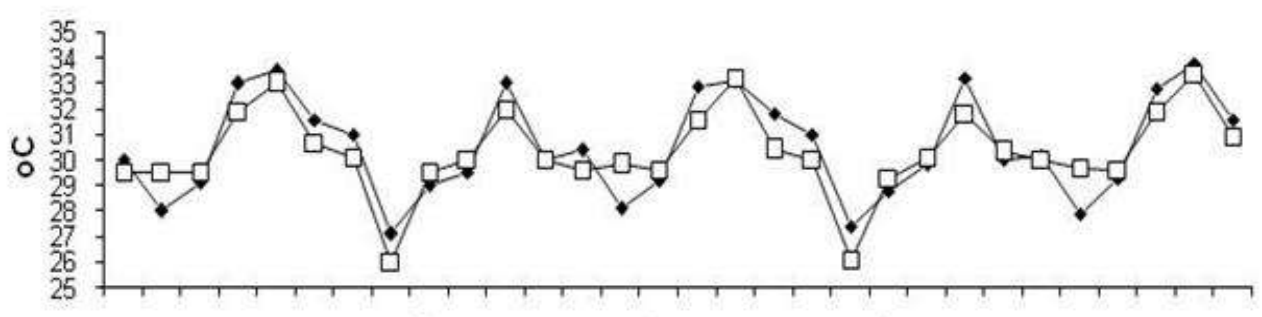

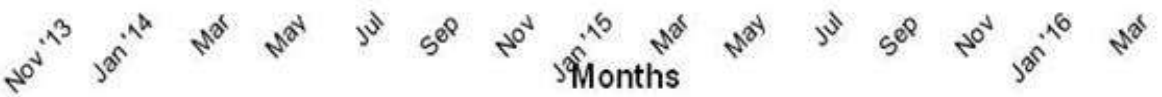

Graph 2: Monthly variation in salinity

$\leadsto$ Zone A

$\rightarrow$-Zone B

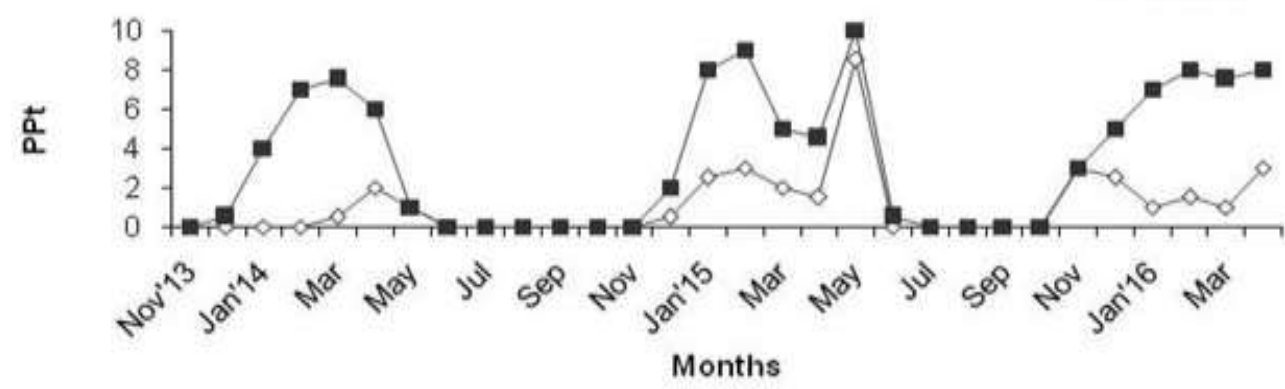

Graph 3: Monthly variation in \% of Sand

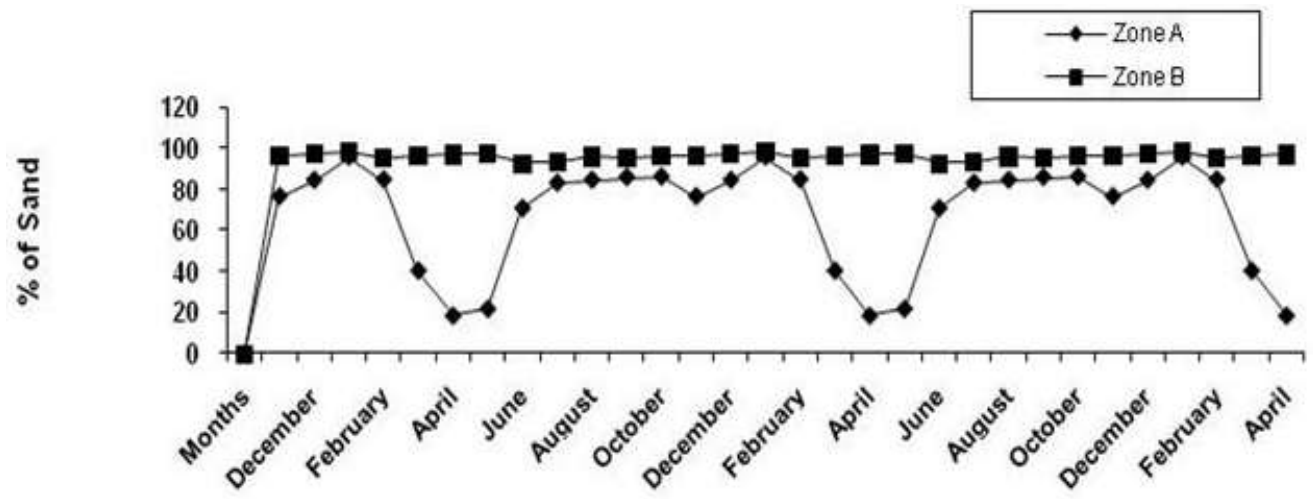

Months

Graph 4: Monthly variation in \% of Silt

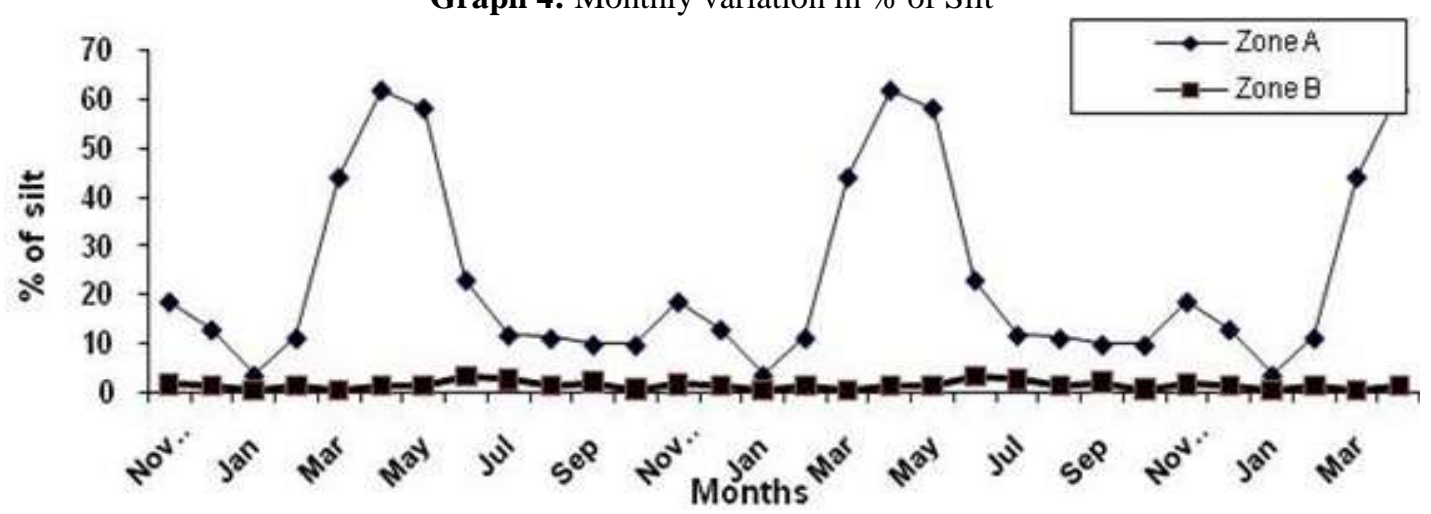

Graph 5: Monthly variation in \% of Clay

Volume 6 Issue 12, December 2017

www.ijsr.net

Licensed Under Creative Commons Attribution CC BY 


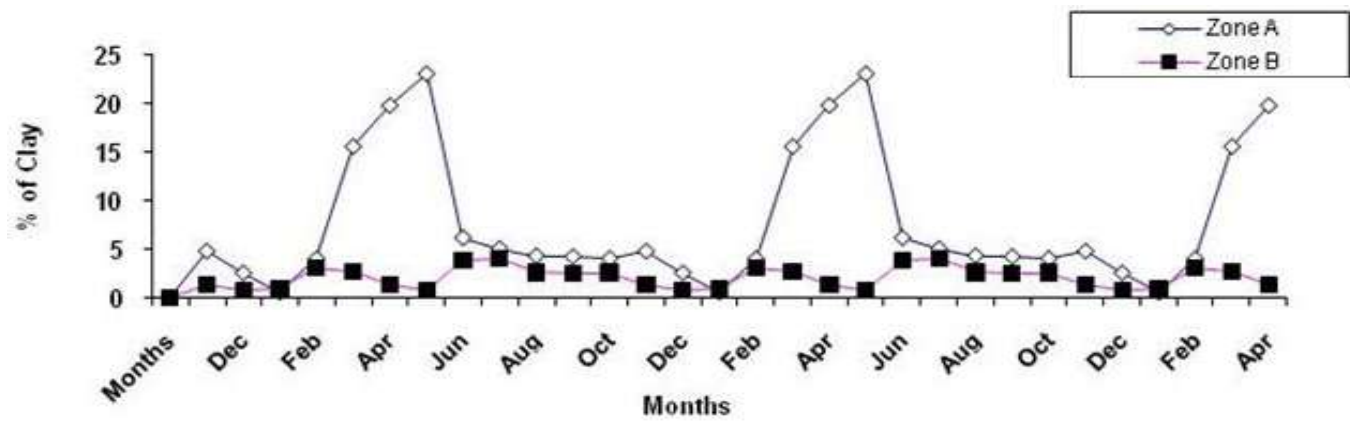

Graph 6: Logarthmic ralationship between different morphometric parameters in Zone A Log L Vs Log Total weight

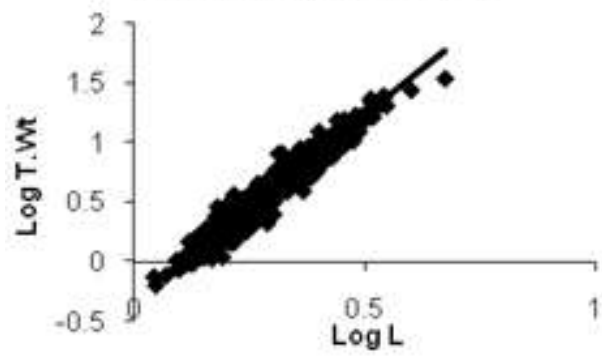

Log L Vs Log D
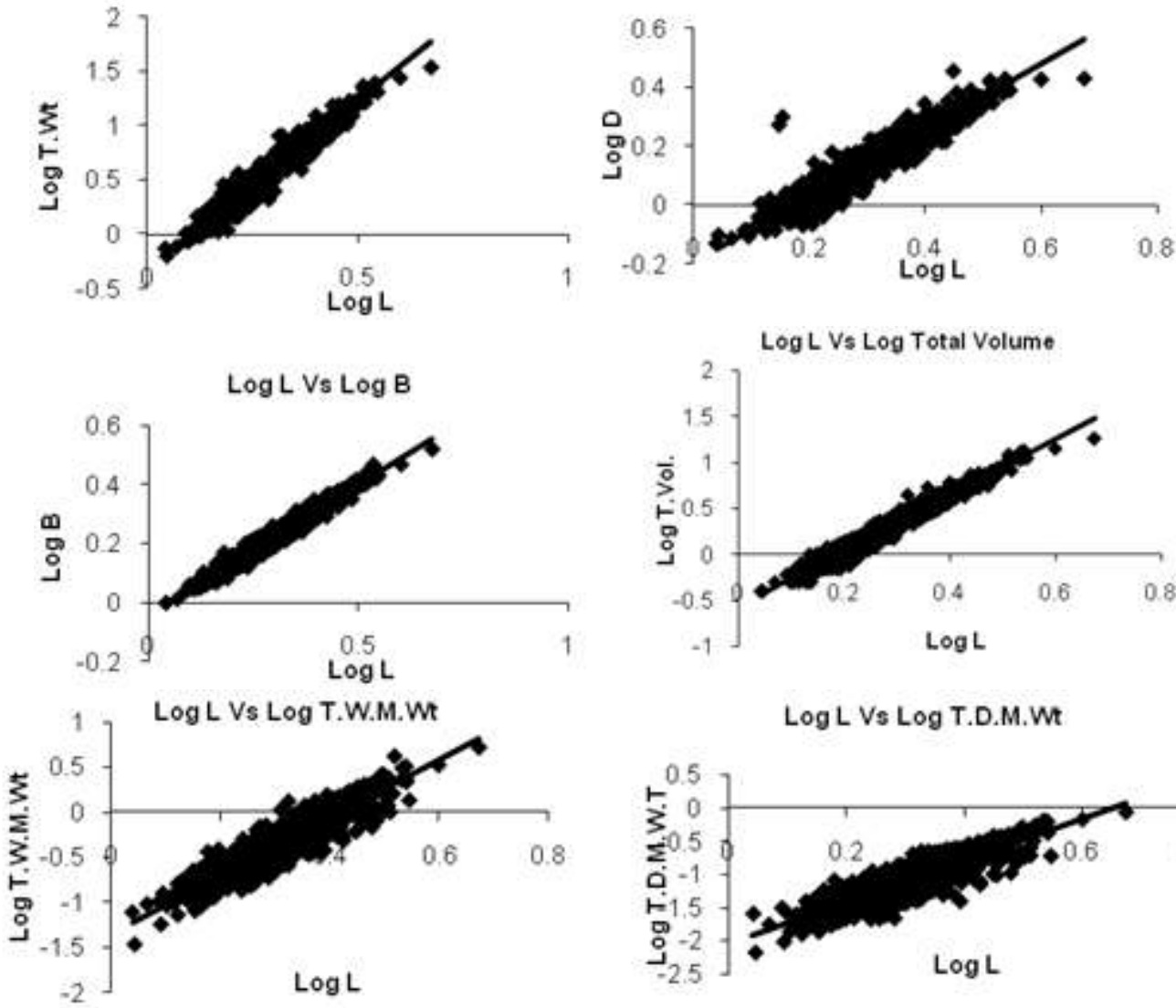

Log L Vs Log T.Sh.W

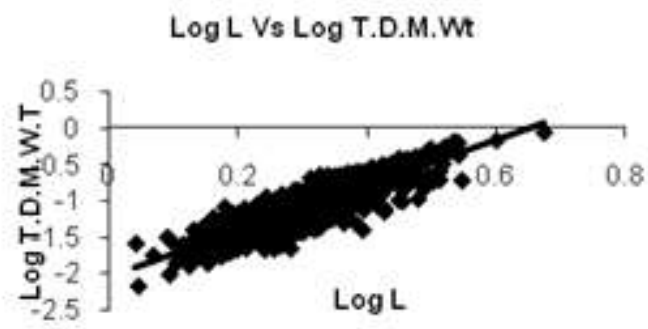

Log L Vs Log T.S.Vol
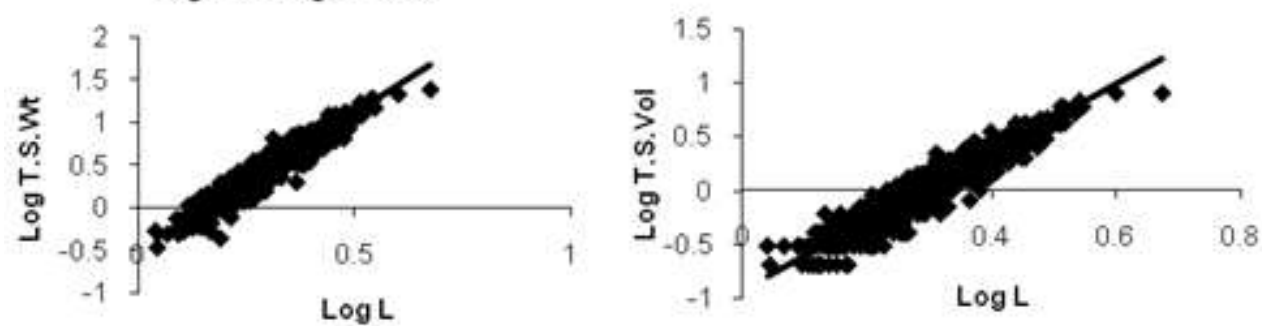

Table 1: Allometric relation between different morphometric parameters in Zone A

\begin{tabular}{|c|c|c|c|c|}
\hline Parameter & $-\log \mathrm{a}$ & $\mathrm{b}$ & R Square & Numbers \\
\hline L Vs B & 0.03988 & 0.880042 & 0.97 & 3000 \\
\hline L Vs D & 0.19394 & 1.118062 & 0.9 & 3000 \\
\hline L Vs T.W & 0.32202 & 3.115346 & 0.95 & 3000 \\
\hline L Vs T.Vol & 0.56485 & 3.026343 & 0.97 & 3000 \\
\hline L.Vs .W.M.Wt & 1.34991 & 3.223267 & 0.86 & 3000 \\
\hline L Vs T.D.M.Wt & 2.05262 & 3.153856 & 0.77 & 3000 \\
\hline L Vs T.D.S.Wt & 0.50248 & 3.23991 & 0.93 & 3000 \\
\hline L Vs T.D.S.V & 0.92746 & 3.191171 & 0.91 & 3000 \\
\hline
\end{tabular}

Volume 6 Issue 12, December 2017 www.ijsr.net

Licensed Under Creative Commons Attribution CC BY 
International Journal of Science and Research (IJSR)

ISSN (Online): 2319-7064

Index Copernicus Value (2016): 79.57 | Impact Factor (2015): 6.391
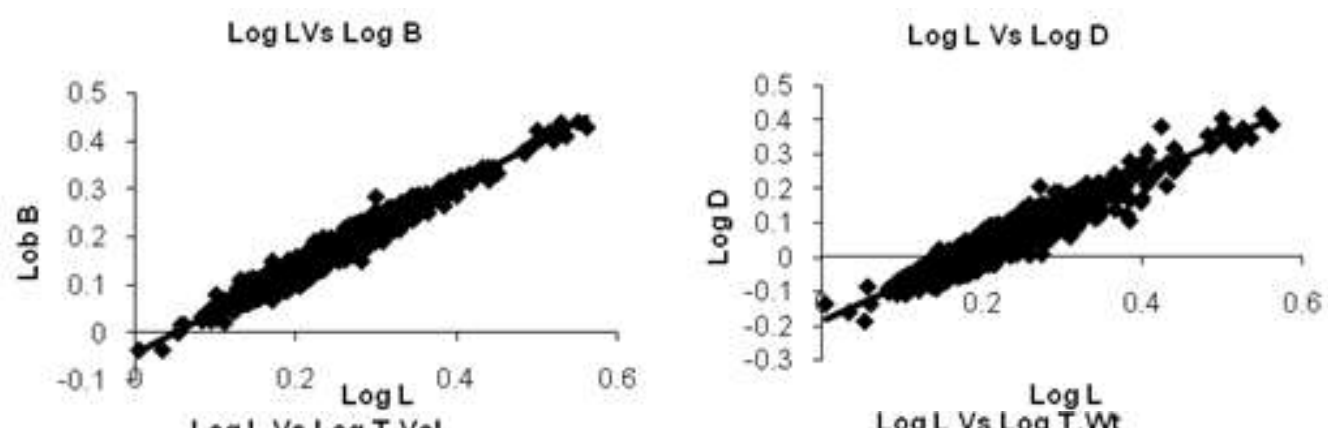

Log L Vs Log T.Vol

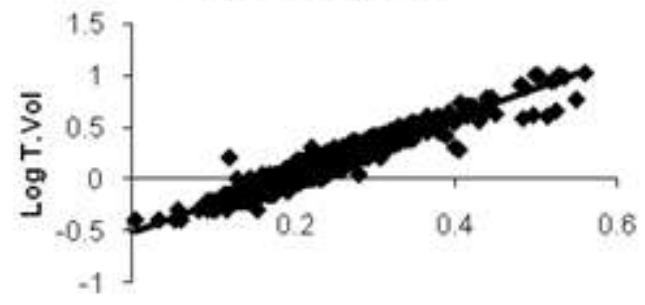

$\log L$

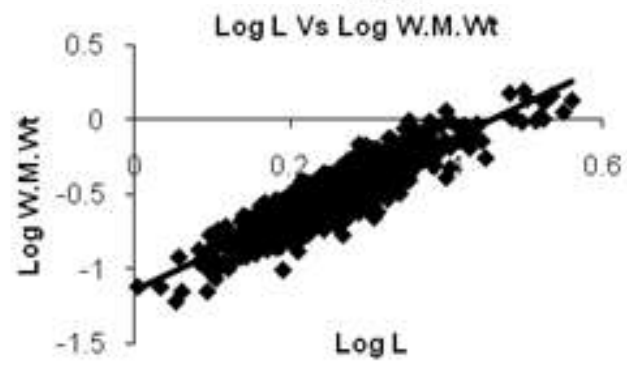

LogL Vs Log T.S.Vol
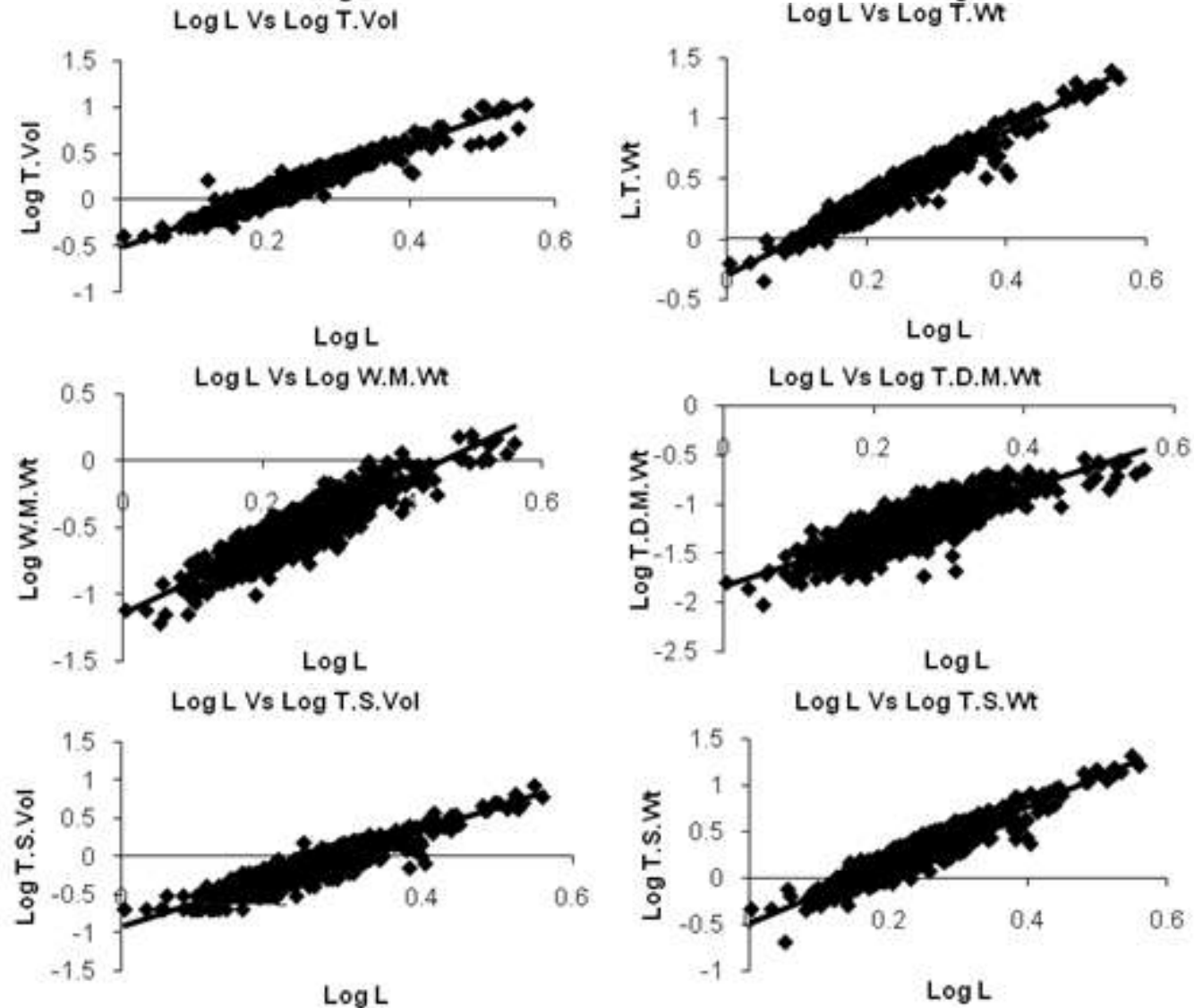

LogL Vs Log T.S.Wt

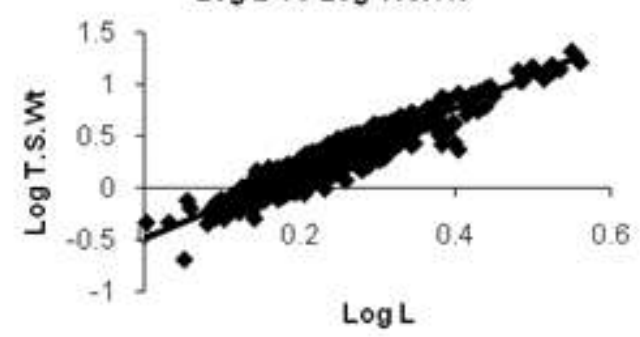

Graph 7: Logarthmic ralationship between different morphometric parameters in Zone B

Table 2 Allometric relation between different morphometric parameters in Zone B

\begin{tabular}{|l|c|c|c|c|}
\hline Parameter & $-\log \mathrm{a}$ & $\mathrm{b}$ & R Square & Numbers \\
\hline L Vs B & 0.04437 & 0.882541 & 0.95 & 3000 \\
\hline L Vs D & 0.18661 & 1.053522 & 0.88 & 3000 \\
\hline L Vs T.W & 0.30463 & 3.001938 & 0.93 & 3000 \\
\hline L Vs T.Vo & 0.51886 & 2.801648 & 0.93 & 3000 \\
\hline L.Vs .W.M.Wt & 1.14458 & 2.492428 & 0.79 & 3000 \\
\hline L Vs T.D.M.Wt & 1.83784 & 2.459307 & 0.63 & 3000 \\
\hline L Vs T.D.S.Wt & 0.4915 & 3.166723 & 0.89 & 3000 \\
\hline L Vs T.D.S.V & 0.92248 & 3.138074 & 0.86 & 3000 \\
\hline
\end{tabular}

Volume 6 Issue 12, December 2017

www.ijsr.net

Licensed Under Creative Commons Attribution CC BY 